\title{
Evaluasi Potensi Gas Serpih pada Batuan Mesozoikum, Formasi Kuantan, West Sumatra Block dengan Menggunakan Metode Restorasi
}

\section{The Potential Evaluation of Shale Gas at Mesozoic Rocks, Kuantan Formation, West Sumatra Block using Restoration Method}

\author{
Yulia Febri Yeni ${ }^{1}$, Riecca Oktavitania ${ }^{2}$, Ollybinar Rizkika ${ }^{2}$ \\ ${ }^{1}$ BOB PT. Bumi Siak Pusako - Pertamina Hulu, Jalan Mega Kuningan Barat NO. 6 Jakarta \\ ${ }^{2}$ Pusat Survey Geologi, Jalan Diponegoro No. 57 Bandung \\ email: Yfeb.geo@gmail.com \\ Naskah diterima : 18 September 2020, Revisi terakhir : 20 November 2020 Disetujui : 23 November 2020, Online : 23 November 2020 \\ DOI: http://dx.doi.org/10.33332/jgsm.geologi.21.4.187-198p
}

\begin{abstract}
Abstrak- Formasi Kuantan merupakan batuan berumur Permo-Karbon yang merupakan bagian dari Blok Sumatra Barat dan pada daerah penelitian dapat dikelompokkan ke dalam tiga satuan, yaitu Satuan Metamorf, Satuan Serpih dan Satuan Batugamping. Serpih Formasi Kuantan diendapkan pada lingkungan pantai yang berasosiasi dengan lingkungan laut.

Total Organic Content (TOC) serpih Formasi Kuantan yang didapatkan dari lima sampel serpih yaitu 0,09\% swt - 0,7\% wt dengan Hidrogen Index (HI) $0-15 \mathrm{mg} / \mathrm{g}$. Berdasarkan hasil analisis geokimia yang dilakukan, serpih Formasi Kuantan jika dilihat dari nilai Hidrogen Indek (HI) yang $<50 \mathrm{mg} / \mathrm{gC}$ didapat kerogen tipe IV dan dari hasil cross plot antara nilai HI dan OI pada diagram van Kravelen, juga memperlihatkan bahwa serpih ini memiliki kerogen tipe IV. Akan tetapi berdasarkan perbandingan persentase vitrinit dengan inertinit, serpih pada daerah penelitian memiliki persentase vitrinit yang lebih besar dibanding inertinit yaitu 6-16\%, sedangkan inertinit berkisar dari 1.6-3,2 \%, sehingga diperkirakan batuan ini bukan berasal dari tipe IV. Nilai TAI serpih di daerah penelitian adalah 2 sampai dengan 2+/3- dengan interval kematangan dari early mature sampai late mature atau sebanding dengan nilai Ro $0.6 \%-0.9 \%$ dan dengan Tmax 435-450.
\end{abstract}

Katakunci: Formasi Kuantan, Permo-Karbon, Blok Sumatra Barat, TOC.

\begin{abstract}
Kuantan Formation is Permo-Carboniferous age rock formation which is part of West Sumatra Block and in the research area can be classified into three units, they are Metamorphic Unit, Shale Unit, and Limestone Unit. Shales of Kuantan Formation deposited on the coastal regions associated with marine environment.

Total Organic Content (TOC) of Kuantan Formation shale obtained from five samples shale is $0.09 \mathrm{wt} \%-0.7 \mathrm{wt} \%$ with Hydrogen Index (HI) 0-15 mg / g. Based on the results of geochemical analysis, Hydrogen Index (HI) value which $<$ $50 \mathrm{mg} / \mathrm{gC}$, the kerogen type of Kuantan Formation shale is type IV, from the cross-plot between HI and OI values on the van Kravelen diagram, also indicates that Kerogen type of Kuantan Formation shale is type IV. However, based on comparison with the percentage of vitrinite and inertinite, shale in the research area has a greater percentage of vitrinite ie 6-16\% whereas inertinite ranged from 1.6-3,2\%, it is estimated that these rocks are not derived from type IV. TAI value of shale in the research area is 2 to $2+13$ - with intervals of maturity from early mature to late mature or similar to the value of Ro $0.6 \%-0.9 \%$ and the Tmax 435 450.
\end{abstract}

Keywords: Kuantan Formation, Permo-Carboniferous, West Sumatra Block, TOC. 


\section{PENDAHULUAN}

Gas serpih adalah gas yang terdapat pada batuan reservoir berbutir halus dan terperangkap di dalamnya. Berbeda dengan hidrokarbon konvensional, gas serpih tidak harus memenuhi persyaratan sistem petroleum karena gas serpih tidak membutuhkan migrasi ataupun batuan penutup.

Eksplorasi dan eksploitasi gas serpih pertama kali dilakukan di Amerika Serikat dengan ditemukannya gas pada serpih Formasi Barnett

di Cekungan Fort Worth, North-Central Texas. Formasi ini telah menghasilkan gas mencapai lebih dari 3,7 triliun kaki kubik (Montgomery dkk., 2005), sehingga Amerika yang dulunya merupakan importir gas sekarang menjadi mandiri dan mendorong turunnya harga gas di negara tersebut.

Wilayah Indonesia bagian barat khususnya Cekungan Sumatra Tengah dan Cekungan Ombilin juga merupakan daerah yang memiliki sebaran serpih yang cukup luas. Selain serpih yang berumur Kenozoikum, daerah ini juga memiliki serpih dengan umur Mesozoikum yang merupakan bagian dari endapan pre-rift. Formasi serpih yang terdapat pada daerah penelitian yaitu Formasi Kuantan, dengan umur Karbon - Perm Awal (Gafoer dkk,.1996) dan merupakan bagian dari Blok Sumatra Barat (Metcalfe, 2011; Barber dkk., 2005).

Serpih Formasi Kuantan memiliki kandungan karbonat $<5 \%$ dan kandungan silika $>50 \%$ (Chalik, 1996) sehingga secara kekerasan batuan ini diperkirakan memiliki brittelness yang bagus secara mekanika. Mineral lempung utama penyusun serpih formasi ini adalah kaolin dan illit (Chalik, 1996).

\section{DATA DAN METODOLOGI PENELITIAN}

Data yang digunakan terdiri atas:

1. Data contoh batuan (hand specimen) untuk dianalisis petrologi, sedimentologi dan analisis geokimia.

2. Data geokimia yang dibutuhkan terdiri atas T-max, Ro (pantulan vitrinit), TOC (Total Organic Carbon), SEM (Scanning Electron Microscope) dan EDX (Energy-dispersive Xray spectroscopy)

Metodologi yang digunakan adalah menggunakan penalaran logika induksi dan deduksi, yaitu dengan melakukan studi literatur, dilanjutkan dengan pekerjaan lapangan untuk pengambilan contoh batuan, selanjutnya dilakukan analisis geokimia, petrologi dan mineralogi batuan. Dari semua pekerjaan tersebut, selanjutnya dibuat analisis potensi gas serpih untuk daerah penelitian.

\section{HASIL DAN DISKUSI}

Daerah penelitian terletak di Kabupaten Tanah Datar, Kabupaten 50 Kota dan Kabupaten Agam, Provinsi Sumatra Barat, sebelah timurlaut Kota Padang (Gambar 1).

\section{Geologi Daerah Penelitian}

Daerah penelitian terletak pada Blok Sumatra Barat yang merupakan bagian dari Gondwana Land (Metcalfe, 2011; Barber dkk., 2005) (Gambar 2\& 3).

Formasi yang terdapat pada daerah penelitian terdiri atas Formasi Kuantan, Satuan Lava Andesit, Satuan Tuf Batuapung, Satuan Breksi Vulkanik dan Satuan Aluvial. Gambar berikut memperlihatkan kolom stratigrafi yeng memperlihatkan susunan stratigrafi di daerah penelitian (Gambar 4).

Formasi Kuantan yang terdapat pada daerah penelitian dapat dikelompokkan menjadi tiga satuan batuan, yaitu: Satuan Metamorf, Satuan Serpih dan Satuan Batugamping.

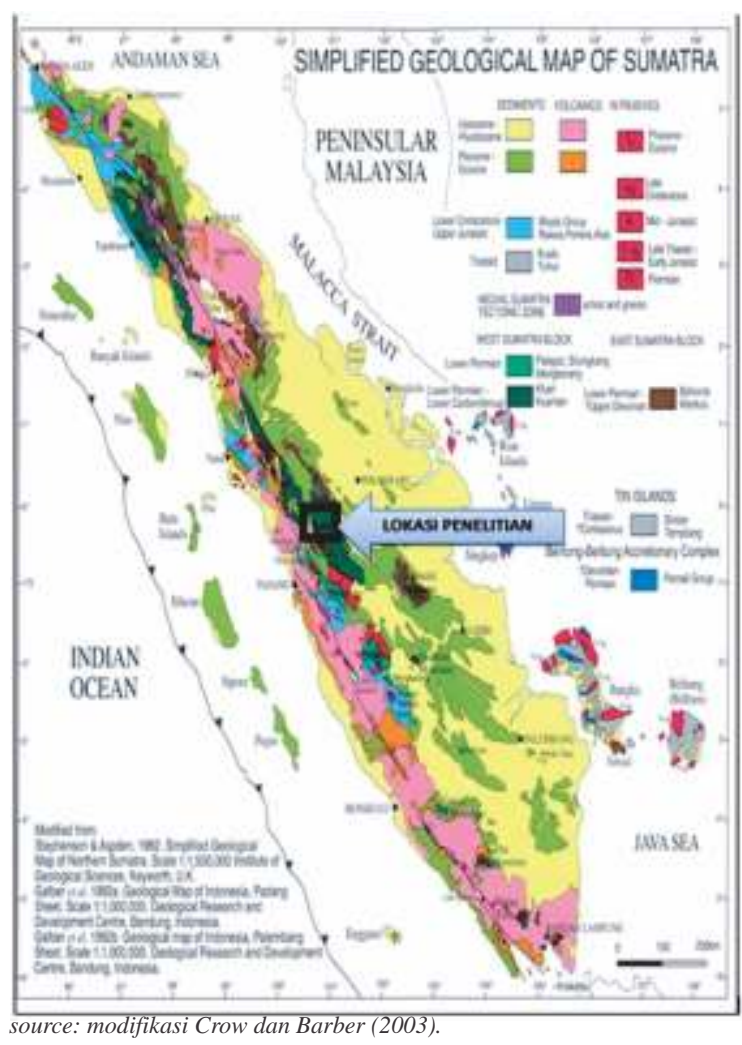

G ambar 1. Lokasi penelitian dan simplifikasi petageologi Sumatra. 


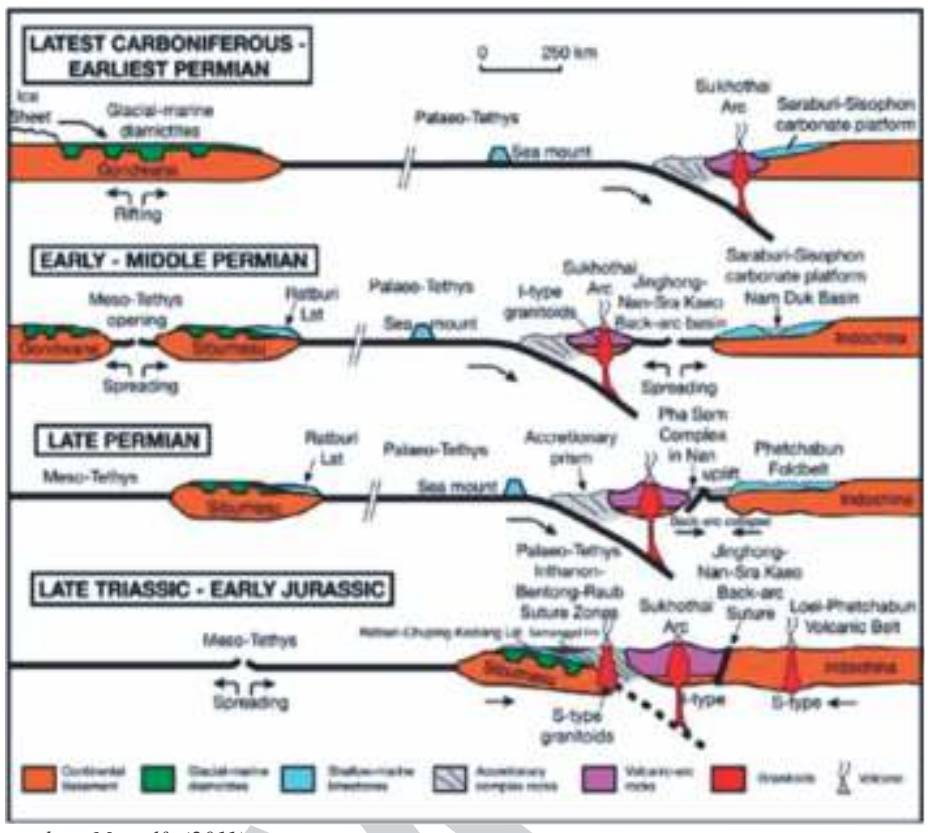

sumber: Metcalfe (2011).

Gambar 2. Gambar yang memperlihatkan evolusi tektonik Sundaland (Thailand - Semenanjung Malaya).

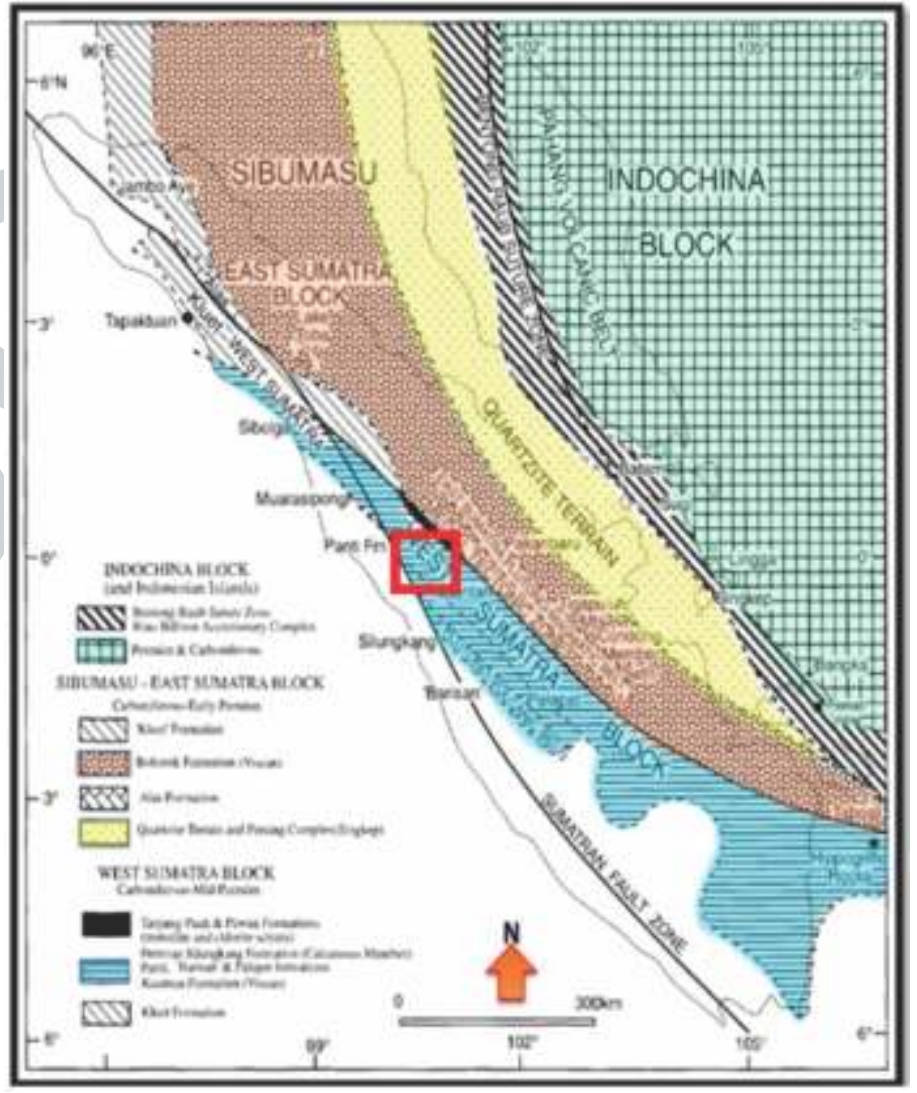

sumber: Barber dkk. (2005).

G ambar 3. Peta pembagian mintakat bagian barat dan timur Sumatra dan jugaBlok Indocina. 


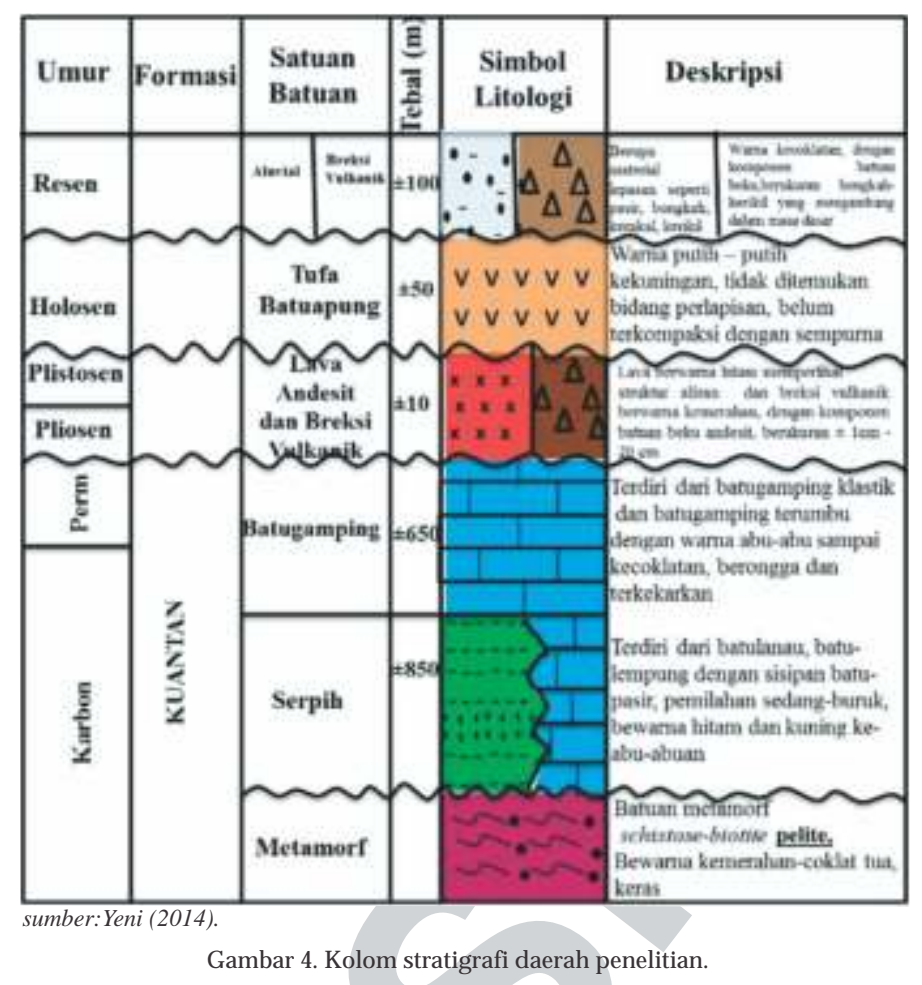

\section{Satuan Metamorf}

Satuan ini memiliki warna kemerahan, kompak, terdapat mineral pirit, dijumpai rekahan yang cukup intensif memotong batuan ini (Gambar 5).

Hasil analisis petrografi memperlihatkan bahwa protolit dari batuan metamorf ini adalah batuan sedimen berbutir halus seperti batulanau sampai dengan batulempung. Berdasarkan analisis sayatan tipis dapat dilihat adanya pengarahan pada butiran kuarsa atau foliasi pada batuan yang menunjukan batuan telah mengalami proses metamorfisme (Gambar6).

Mineral utama penyusun batuan terdiri atas kuarsa 17 $\%$, ukuran butir $0,05-0,1 \mathrm{~mm}$, mika yaitu mineral biotit 3\%, mineral lempung 55\% dengan warna kecoklatan, mineral opaq $2 \%$ yang diperkirakan adalah mineral pirit dengan butiran berukuran 0,1-0,9 $\mathrm{mm}$, karbon $15 \%$ dan oksida besi $8 \%$. Batuan metamorf di daerah penelitian dapat dikelompokkan kedalam pelite dan untuk penamaan yang lebih detail maka tekstur dari batuan ditambahkan di didepannya dan jika ada mineral khusus pencirinya sebaiknya juga ditambahkan, sehingga nama dari batuan metamorf ini adalah schistose-biotite.

\section{Satuan Serpih}

Satuan batuan ini terdiri atas batulanau, batulempung dengan sisipan batupasir, ukuran butir berkisar dari lempung sampai dengan pasir sedang, dengan pemilahan sedang-buruk, terdapat mineral pirit dan urat kuarsa yang memotong satuan ini di beberapa tempat.

Serpih dengan warna hitam kadang kuning keabu-abuan, tersingkap dengan baik di daerah Padang Tarok (St.41 sampai dengan St.42), Bayua (St.32 sampai dengan St.36), Talao (St.9 sampai dengan St.18), Sei. Cubadak (St.1 sampai dengan St.8) dan Tabek Patah (St.31 dan St.32) dengan kenampakan di lapangan menyerpih sebagain dan ada juga yang masih memperlihatkan struktur sedimen laminasi (Gambar 7).

Mineral utama penyusun serpih ini terdiri atas kuarsa \pm $25 \%$ berukuran $0,02-0,3 \mathrm{~mm}$, mineral opaq $\pm 5 \%$ dengan warna hitam, bentuk butir menyudut-menyudut tanggung berukuran $0,02-0,05 \mathrm{~mm}$, karbon $\pm 10 \%$ dan mineral lempung $\pm 50 \%$, dengan warna coklat keruh, mika $1 \%$ dan oksida besi berwarna kecoklatan $\pm 9 \%$ dengan porositas $\pm 1 \%-3 \%$. Porositas yang berkembang terdiri atas rekahan dan disolusi yang disebabkan oleh pelarutan butiran yang tidak stabil dan sebagian juga sudah terisi oleh mineral silika, kalsit dan oksida besi (Gambar 8).

Selain serpih pada satuan ini juga terdapat batupasir yang hadir sebagai sisipan dengan ketebalan $45 \mathrm{~cm}-1,5 \mathrm{~m}$. Batupasir pada satuan ini, terdiri atas dua yaitu lithic arenite dan quartz arenite. 


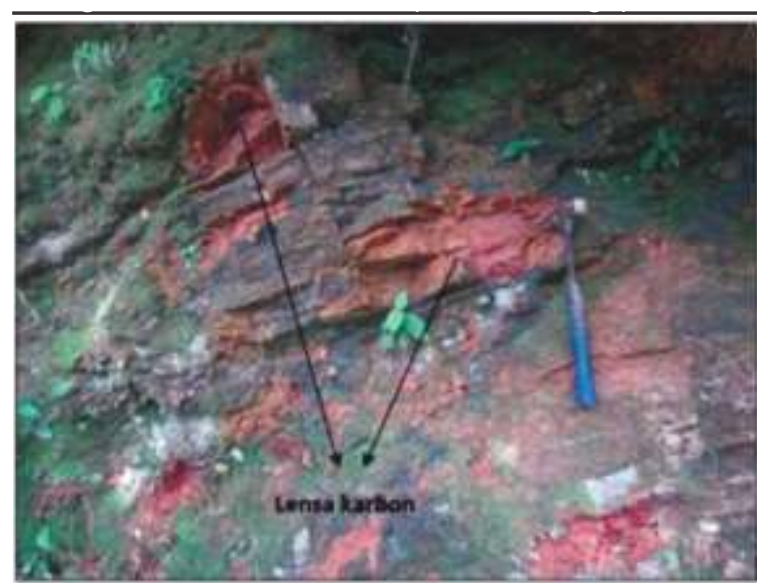

G ambar 5. Foto singkapan batuan metamorf daerah Sei. Sariak, bewarna kemerahan dan terdapat lensa karbon berwarnahitam di dalamnya.

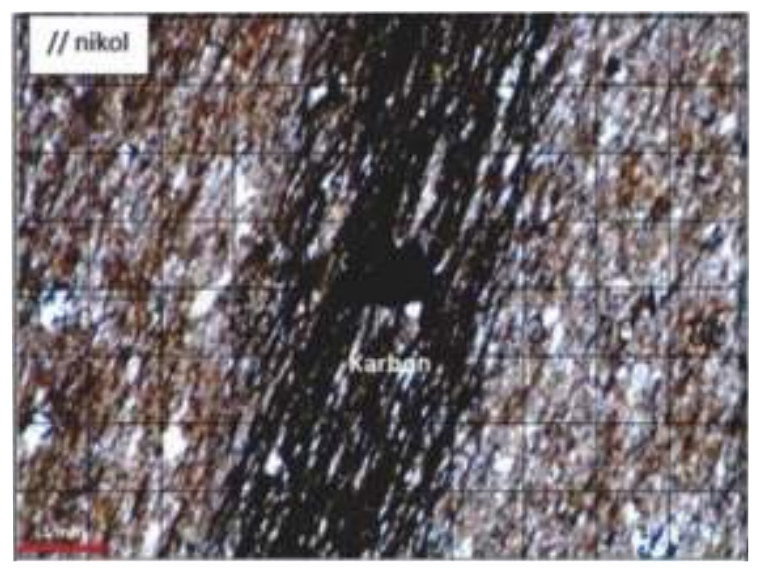

Gambar 6. Foto salah satu tipis sayatan batuan metamorf, padaluasan sayatan memperlihatkan adanya pengarahan pada butiran kuarsa, terdapatmineral opaq (pirit) dan karbon.

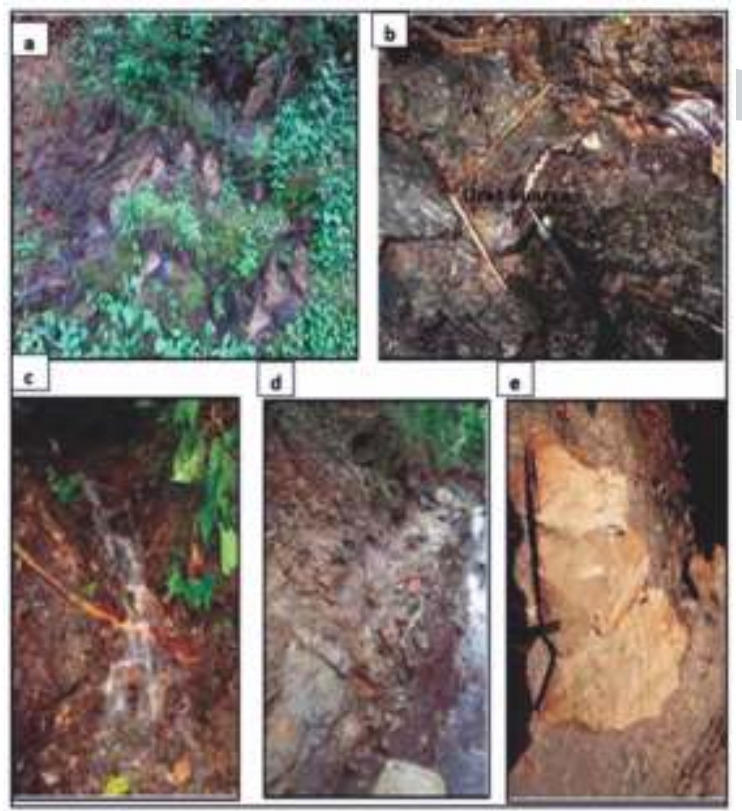

G ambar 7. Foto singkapan serpih (a) Serpih dengan intensitas rekahan yang tinggi di Talao (St.9) (b) Serpih Tabek Patah yang terisi urat kuarsa (St.31) (c) Singkapan serpih Sei. Cubadak (St.3) (d) Serpih daerah Padang Tarok (St.41) (e) Struktur paralel laminasi yang masih bisa teramati disalah satu singkapan serpih daerah Talao (St.16).
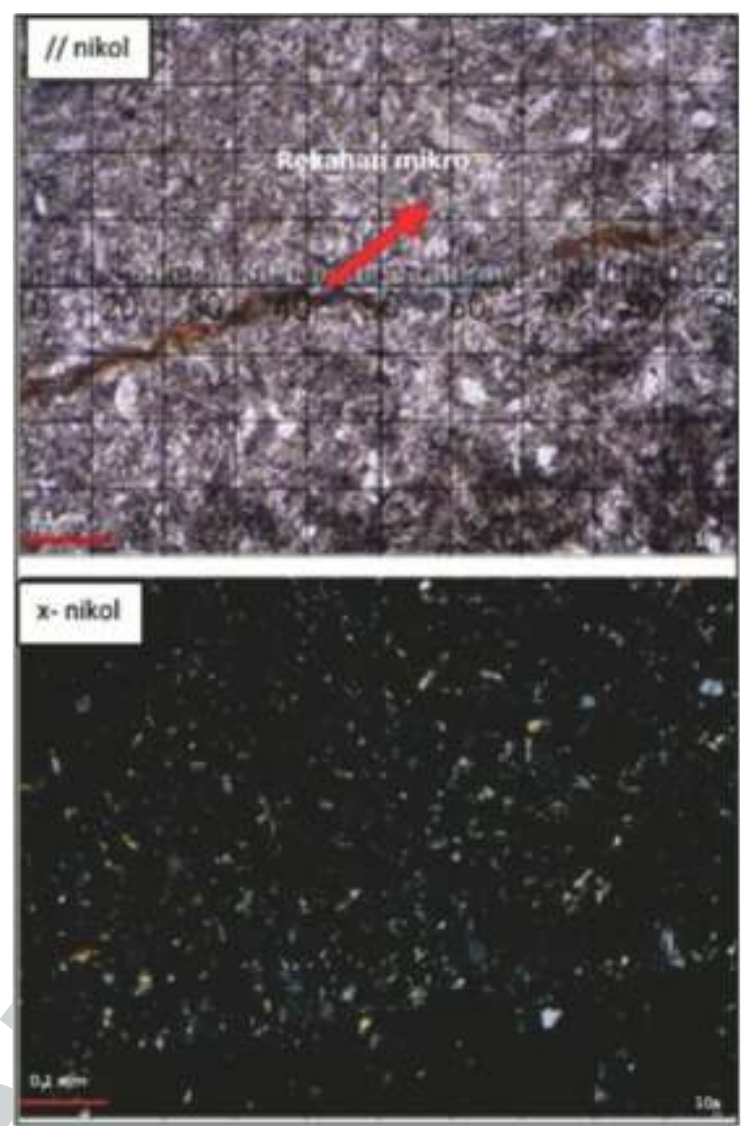

Gambar 8. Foto sayatan tipis serpih Tabek Patah lokasi St.31, terdapat rekahan mikroyang terisi oksida besi.

\section{Umur dan Lingkungan Pengendapan}

Berdasarkan ciri litologi yang diuraikan secara mikroskopis dan makroskopis dari Satuan Serpih dan juga dengan kehadiran batupasir arenit yang diperkirakan diendapkan pada sebuah sistem arus traksi yang sangat bersih dari butiran halus. Lingkungan pengendapan diperkirakan pada daerah pantai yang berasosiasi dengan laut dangkal.

Selama penelitian tidak dijumpai kontak antara satuan ini dengan satuan yang ada di bawahnya. Hanya saja fakta-fakta berikut memberikan indikasi bahwa satuan ini diendapkan secara tidak selaras non conformity, dengan data sebagai berikut:

1. Bahwa batuan di bawah sudah termetamorfkan, sedangkan batuan serpih masih memperlihatkan karakter batuan sedimen walaupun sudah mengalami diagenesis yang cukup lanjut.

2. Di dalam batupasir terdapat fragmen kuarsa yang bersifat polikristalin yang mengindikasikan batuan sumbernya (provenance) adalah batuan metamorf. Sangat boleh jadi, butiran-butiran pasir ini bersumber dari batuan dasar atau satuan yang lebih tua yang telah mengalami proses metamorfosa. 
Berdasarkan kesebandingan regional, satuan serpih Formasi Kuantan diendapkan pada umur Akhir Karbon Awal.

\section{Satuan Batugamping}

Kenampakan di lapangan satuan batugamping ini memiliki warna putih keabu-abuan dalam kondisi segar, sedangkan dalam kondisi lapuk bewarna putih kehitaman, masif, kompak, di beberapa tempat menunjukkan kesan seperti berlapis dengan intensitas rekahan yang tinggi, terdapat juga batugamping terumbu. Satuan batugamping ini dapat dilihat di sepanjang ruas jalan Bukittinggi-Payakumbuh.

Berdasarkan hasil penelitian terdahulu yang dilakukan oleh Chalik (1996), batugamping pada daerah penelitian dapat dikelompokkan menjadi batugamping wackestone yang terletak pada lintasan PLTA Batang Agam lokasi G12, batugamping mudstone yang tersingkap pada daerah Sei Angek lokasi Gm10 dan batugamping terumbu yang terletak pada daerah Sei Angek lokasi G19 (Gambar9).

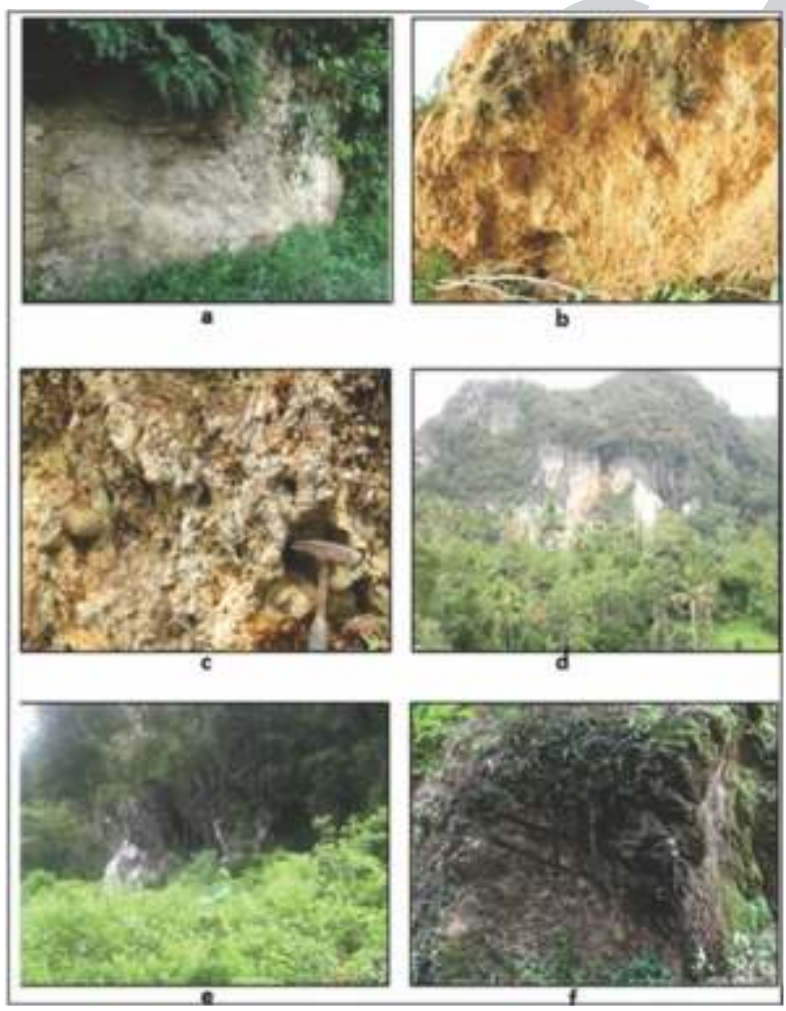

Gambar 9. Foto singkapan batugamping yang terdapat pada daerah penelitian (a) batugamping mudstone Sei Angek lokasi Gm10 (b; c \& d) batugamping masif pada daerah Sei Angek lokasi G19 (e) batugamping wackestone pada daerah PLTA Batang Agam lokasi G12 dan (f) batugamping berlapispadadaerah Kamang lokasi G1.

\section{Umur dan Lingkungan Pengendapan}

Pada penelitian ini tidak dilakukan penelitian khusus pada interval batugamping ini karena fokus penelitian pada serpih dan berdasarkan penelitian terdahulu (Fontaine dan Gafoer, 1989; Chalik, 1996). Batugamping yang tersingkap di sepanjang Batang Agam di dekat jembatan yang terletak di jalan Bukittinggi-Pekanbaru ditemukan alga Konockopora dan foraminifera Paleotextularia yang berumur Perem Awal, Eondothyranopsis dan Archaediscus yang mengindikasikan umur Mid-Visean (Pertengahan Karbon Awal). Beberapa sampel lain yang ditemukan menunjukan rentang umur Early Mid Visean - Late Visean. Umur Mid-late Vicean didapat dengan ditemukannya fosil Conodonts termasuk Gnathodus girty rhodesi Higgins pada daerah ini (Metcalfe, 1983).

Batugamping yang tersingkap di sepanjang Sungai Kuantan terdiri atas koloni besar koral yang terdiri atas tabulate coral Syringopora, fasciculate Tetracorallia Siphenodendron and the alga Koninckopora inflate, mengindikasikan umur Late Visean (Karbon Awal) (Fontaine \& Gafoer 1989; Vachard 1989a, b). Ciri-ciri koral ini mirip dengan koral yang ditemui di daerah Sei Angek. Batugamping ini terdiri atas koloni koral Syringopora dan intratidal algal mats, yang biasanya diendapkan pada daerah sub-tropis - tropis di lingkungan laut dangkal yang hangat. Ketebalan dari satuan ini adalah $\pm 650 \mathrm{~m}$. Diperkirakan umur satuan batugamping ini dari pertengahan Karbon Awal - Perem Awal dengan kontak menjemari dengan Satuan Serpih.

\section{Potensi Gas Serpih}

Dalam penelitian gas serpih ada beberapa parameter yang harus diperhatikan (EIA, 2011). Berikut adalah parameter yang digunakan untuk melihat potensi satuan serpih sebagai nonkonvensioanl reservoir:

\section{Lingkungan pengendapan}

Lingkungan pengendapan merupakan salah satu kriteria penting yang diperhatikan dalam penelitian gas serpih, apakah berasal dari lingkungan laut atau bukan laut. Serpih yang diendapkan di lingkungan laut biasa memiliki kandungan mineral lempung yang lebih sedikit dan memiliki kandungan mineral yang lebih brittle seperti kuarsa, feldspar dan karbonat. Serpih yang diendapkan di lingkungan danau atau darat biasanya akan memiliki kandungan mineral lempung yang lebih tinggi dan lebih ductile sehingga memiliki respon yang kurang bagus jika dilakukan simulasi hydraulic fracturing. 


\section{Penentuan kedalaman}

Kedalaman yang ideal untuk gas serpih adalah lebih dari $1000 \mathrm{~m}$ tetapi kurang dari $5000 \mathrm{~m}(3300-16500$ $\mathrm{ft}$ ). Area yang kurang dari $1000 \mathrm{~m}$ biasanya memiliki tekanan yang rendah dan konsentrasi gas yang rendah. Formasi gas serpih yang dangkal memiliki resiko kandungan air yang tinggi karena kontak dengan rekahan yang terdapat pada daerah tersebut, sedangkan area dengan kedalaman lebih dari $5000 \mathrm{~m}$ memiliki resiko karena semakin berkurangnya permeabilitas dan biaya pengeboran dan pengembangan yang lebih mahal.

\section{Kandungan Organic (TOC)}

Secara umum, TOC pada daerah prospek sama atau besar dari 2\%. Material organik seperti mikro organisme dan tumbuhan menghasilkan karbon, oksigen dan atom hidrogen yang dibutuhkan dalam membentuk gas dan minyak.

\section{Kematangan}

Area prospek gas serpih idealnya memilki Ro $>1 \%$, semakin tinggi nilai Ro porositas berukuran nano juga akan bertambah sehingga akan menambah porositas dari batuan tersebut (Gambar 10).

\section{Lokasi Geografi}

Daerah yang prospek gas serpih sebaiknya berada di daratan dari cekungan gas serpih tersebut.

\section{ANALISIS GAS SERPIH}

\section{Kekayaan}

Analisis kekayaan dilakukan untuk mengetahui Total Organic Carbon (TOC) dari serpih Formasi Kuantan pada daerah penelitian. Dari hasil 5 sampel serpih, didapat TOC 0,09\% wt - 0,7\% wt dengan Hidrogen Index (HI) $0-15 \mathrm{mg} / \mathrm{g}$ dengan potensi hidrokarbon bagus-buruk (Tabel 1).

\section{Tipe Kerogen}

Berdasarkan hasil analisis geokimia yang dilakukan terhadap lima sampel serpih Formasi Kuantan jika dilihat dari nilai Hidrogen Indek (HI) yang $<50$ $\mathrm{mg} / \mathrm{gC}$ didapat kerogen tipe IV dan dari hasil cross plot antara nilai HI dan OI pada diagram van Kravelen, juga memperlihatkan bahwa serpih ini memiliki kerogen tipe IV (Gambar 11). Akan tetapi dari perbandingan persentase vitrinit dengan inertinit, serpih pada daerah penelitian memiliki persentase vitrinit yang lebih besar dibanding inertinit yaitu 6-16\%, sedangkan inertinit berkisar dari 1.6-3,2 \%, sehingga diperkirakan batuan ini bukan berasal dari tipe IV. Dari analisis batuan secara megaskopis dan mikroskopis baik dari petrografi dan SEM serpih daerah penelitian banyak mengandung pirit, mengindikasikan batuan diendapkan dalam lingkungan reduksi, bukan dalam lingkungan pengendapan yang mengalami oksidasi.

Kerogen tipe I, II dan III bisa berubah menjadi tipe IV karena meningkatnya tingkat kematangan akibat suhu yang tinggi. Suhu yang tinggi atau sampel batuan yang diambil dipermukaan dan telah mengalami oksidasi dan pencucian oleh air permukaan akan mengalami perubahan dengan betambahnya unsur karbon (C) dan mulai kehilangan unsur hidrogen $(\mathrm{H})$ dan oksigen $(\mathrm{O})$ karena mengeluarkan senyawa $\mathrm{H} 2 \mathrm{O}$ dan $\mathrm{CH} 4$.

Berdasarkan analisis petografi ditemukan grafit, yaitu karbon mati yang diperkirakan disebabkan oleh batuan yang mengalami temperatur yang cukup tinggi sehingga menyebabkan kandungan organik hilang dan berubah menjadi grafit.

Tabel 1. Potensi dan Analisis Data Rock Eval Pirolisis.

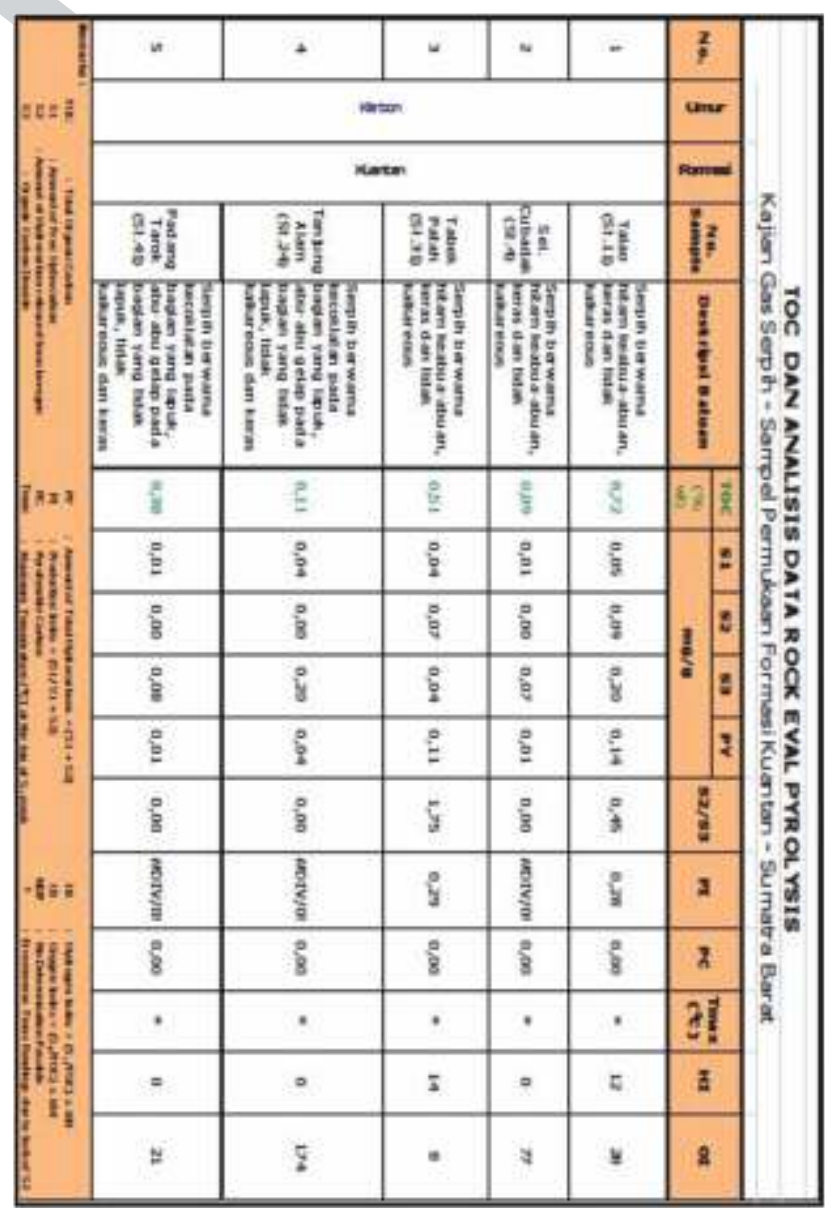




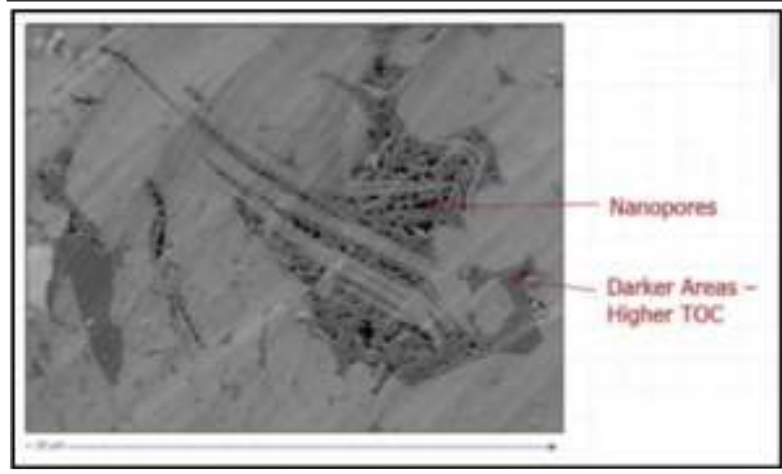

G ambar 10. Gambar IV.1 Contoh porositas berukuran nano (EIA, 2011).

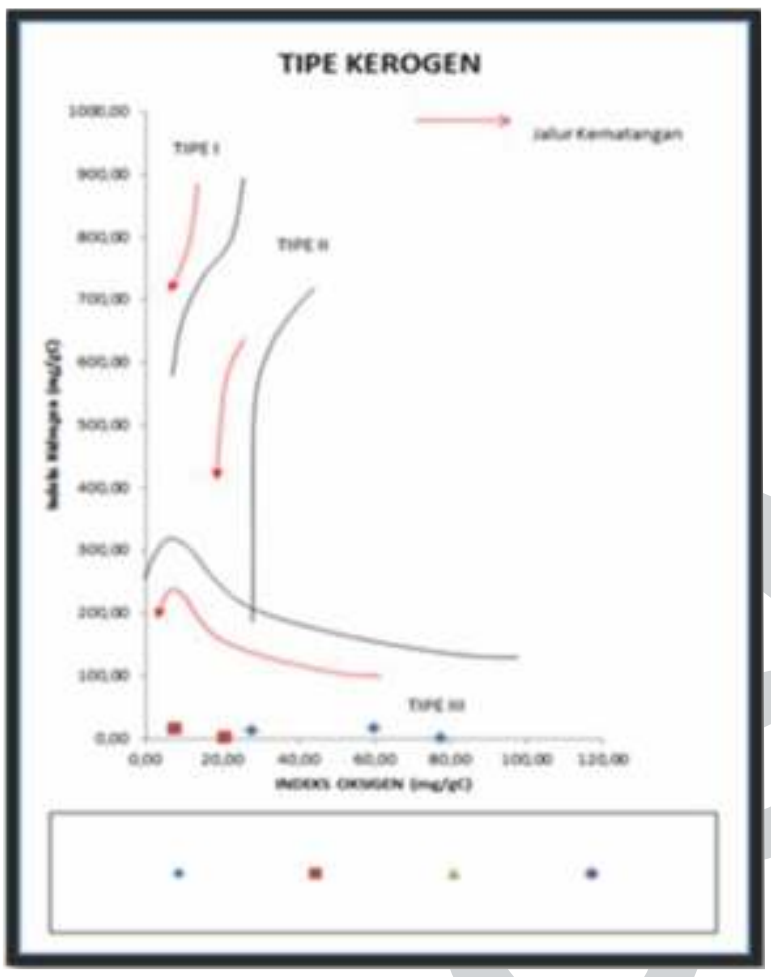

Gambar 11. Crossplot HI vs OI menunjukan kerogen tipe IV dengan H di bawah $50 \mathrm{mg} / \mathrm{gC}$.

\section{Kematangan}

Untuk mengetahui kematangan dari suatu batuan serpih dapat diketahui dari nilai Ro atau nilai Tmax, akan tetapi dari lima sampel serpih yang dianalisis tidak didapat nilai Ro dan Tmax sehingga digunakan korelasi antara Thermal Alteration Index (TAI) yang dapat digunakan untuk mengetahui kematangan batuan serpih (Petter dan Cassa, 1991). Nilai TAI pada serpih daerah penelitian adalah 2 sampai dengan $2+/ 3-$ dengan interval kematangan dari early mature sampai late mature atau sebanding dengan nilai Ro $0.6 \%$ 0.9\% dan dengan Tmax 435-450, akan tetapi jika dilihat dari kehadiran grafit pada sayatan tipis interval kematangan serpih diperkirakan telah memasuki tahap overmature.

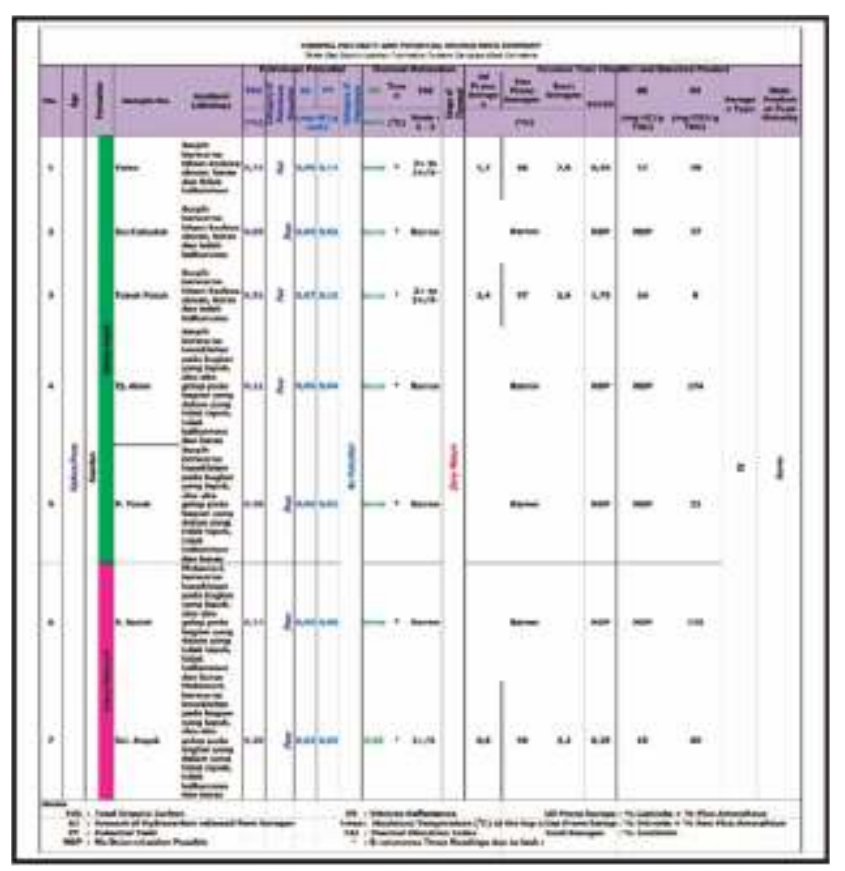

Restorasi

Alasan dilakukannya restorasi adalah karena persentase nilai vitrinit $(6 \%$ - 16\%) lebih besar dibandingkan persentase nilai inertinit $(1,6 \%-3,2 \%)$, sehingga diperkirakan serpih bukan berasal dari tipe IV. Juga berdasarkan analisis lingkungan pengendapan serpih Formasi Kuantan diperkirakan diendapkan pada lingkungan lingkungan laut yang biasanya akan menghasilkan kerogen tipe II atau tipe III. Restorasi dilakukan untuk mengetahui nilai awal dari TOC, dan total hidrokarbon yang telah hilang. Sampel batuan yang dianalisis berlokasi dekat dengan daerah vulkanik aktif yang memiliki temperatur yang tinggi, diperkirakan menyebabkan serpih menjadi overmature dengan ditemukannya grafit pada sayatan tipis dan juga kondisi sampel yang tidak segar karena telah tersingkap di permukaan diperkirakan juga menyebabkan berkurangnya nilai HI dan TOC dari serpih sehingga hasil analisis geokimia memiliki nilai yang sangat kecil. Dalam melakukan restorasi diasumsikan $\mathrm{HI}$ awal, yaitu berkisar antara $300 \mathrm{mg} / \mathrm{g}$ sampai dengan $600 \mathrm{mg} / \mathrm{g}$ untuk tipe II. Untuk perhitungan restorasi, dengan data yang ada maka akan didapat nilai rasio transformasi (Tr) dari sampel serpih yang didapat (Dahl dkk., 2004; Justwan dan Dahl., 2005).

$$
T_{r}=\frac{\frac{1}{a} \times 100 \times\left(H I^{0}-H I^{d}\right)}{H I^{0} \times\left(\frac{1}{a} \times 100-H I^{d}\right)}
$$


Dan nilai rasio transformasi dapat digunakan untuk mengetahui S2 awal dan TOC awal dengan persamaan seperti di bawah ini.

$$
\begin{gathered}
S 2^{0}=\frac{S 2}{1-T_{r}} \\
T O C^{0}=T O C+\frac{S 2 \times T_{r}}{1-T_{r}} \times \alpha
\end{gathered}
$$

Nilai a merupakan nilai konstanta dengan mengasumsikan komposisi elemen gross yang terbentuk sebagai produk hidrokarbon. Nilai konstanta ini didapatkan dari persamaan sederhana yaitu:

$$
\alpha=0.1 C /(C+g H),
$$

$\mathrm{C}$ dan $\mathrm{H}$ adalah berat atom karbon dan hidrogen, $\mathrm{g}$ merupakan nomor dari atom-H. Komposisi S2 merupakan komposisi gross dari Ch2. Berdasarkan pernyataan di atas, maka di dapat nilai $\mathrm{a}=0,0086$ dengan idikasi $86 \%$ wt dari hidrokarbon adalah karbon. Berikut adalah tabel restorasi data geokimia tiga batuan sampel pada daerah penelitian, yaitu satu sampel batuan metamorf dan dua sampel serpih

Di bawah ini adalah contoh restorasi yang dilakukan pada salah satu sampel batuan serpih pada daerah Talao (Tabel 3 \& Gambar 12).

Dari hasil restorasi pada sampel di daerah Talao didapat $\mathrm{S} 2$ awal antara 3,0-9,2 $\mathrm{mg} / \mathrm{g}$ dan TOC awal antara $0,97-1,5 \%$ wt dengan mengasumsikan batuan berasal dari tipe II memiliki nilai HI 300-600 mg/g (Peter dan Cassa, 1996). Dari perhitungan di atas maka dapat diketahui total hidrokarbon yang telah

\begin{tabular}{|c|c|c|c|c|c|c|c|}
\hline \multicolumn{8}{|c|}{ ASUMS } \\
\hline$a$ & iil' & TI & $\mathbb{2}^{\prime}$ & TOC & 52 lont & ToC lest & 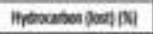 \\
\hline 0,068 & 15 & 5 0,20058s & of $0.112 \pi 8$ & 6. 0.35 & $60,002 \pi$ & 4. 0,00135 & $20,2065 s u 2$ \\
\hline acse & 50 & $0.27 \pi 25$ & 50387006 & 50,745611 & 0.287006 & 6 0.025611 & 76.77245555 \\
\hline 0,006 & 100 & $0,0,89917$ & 40812101 & $10, \pi 2 a n$ & a, mato: & 1] 0,852) & 8.9172094 \\
\hline 0,000 & 130 & 0,525593 & 1278089 & $90,0,2323$ & 1.15509 & 90,222293 & 92,59634095 \\
\hline 0,006 & 200 & 0,549602 & 2. 1,760095 & 90,86649 & 1,700209 & 9 0,54549 & stactusse \\
\hline 0.085 & 250 & 0.56250 & 7) 230305 & 50,515554 & 42273605 & 50,195554 & $\$ 6,1000675$ \\
\hline $0,0,6$ & 30 & 0,950011 & 3001051 & 10,97035 & 5911051 & 150.25875 & 97,001 tsten \\
\hline 0,056 & 330 & 0,975784 & $3,7,16009$ & 9 1,938в & 3.50600 & 90,311398 & $97,5 \pi 4366$ \\
\hline 0,80 & 500 & 5036515 & 435896 & 6) 1,250494 & $4,4,63596$ & 60,365454 & 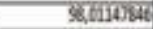 \\
\hline 0,086 & 450 & 0,39363 & 5,45891 & 1.186065 & 5 5, 35891 & 12 Q 455065 & 58,3428766 \\
\hline o,oed & 500 & 0,39612 & 2011083 & 1,27221 & 1. 6,421059 & 3) 0,552221 & 98.617356 \\
\hline 0,068 & 550 & 0,980382 & 2.706546 & 6. 1.3344] & ] 7,656505 & 6. 0,65464$]$ & 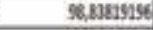 \\
\hline 0,005 & 600 & 0,590203 & 9,2015 & 7. 1,58:3595 & 5. 9.11157 & $7 \mid 0,732555$ & 98,0026607 \\
\hline
\end{tabular}
hilang yaitu hampir mencapai $99 \%$.

Tabel 3. Restorasi TOC awal dan S2 awal Talao

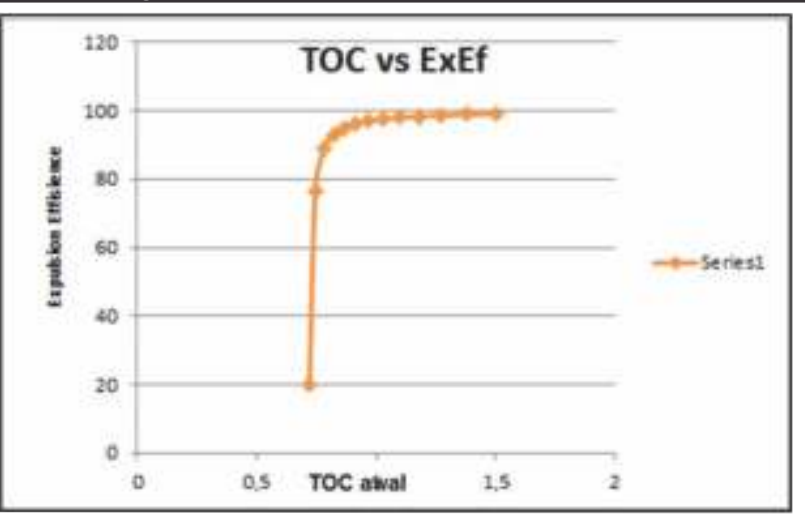

G ambar 12. Cross plot TOC awal dengan total hidrokarbon yang hilang.

\section{Analisis SEM dan E dax}

Analisis SEM dilakukan untuk mengetahui jenis mineral yang terdapat pada sampel batuan secara lebih detail jika dibandingkan dengan hanya menggunakan analisis sayatan tipis. Dengan melakukan analisis SEM dapat diketahui jenis mineral lempung, jenis porositas yang berkembang dan juga rekahan mikro. Selain SEM juga dilakukan analisis EDX, yaitu analisis kimia batuan yang menghasilkan persentase dari unsur kimia yang terdapat pada serpih yang secara prinsipnya hampir sama dengan analisis XRD.

Berdasarkan analisis batuan dan stratigrafi, serpih yang terdapat pada daerah penelitian merupakan serpih yang diendapkan di lingkungan darat sampai dengan transisi pada umur Karbon Awal. Sampel batuan berjumlah empat terdiri atas tiga sampel serpih dan satu sampel batuan metamorf. Dari hasil analisis SEM dan EDX tampak bahwa ilit, klorit dan kaolin merupakan mineral lempung utama dalam batuan serpih dan kuarsa hadir sebagai komponen utama penyusun batuan. $\mathrm{SiO} 2$ yang hadir dalam batuan $40 \%-95 \%$. Berikut adalah contoh hasil analisis EDX dan SEM dari salah satu sampel batuan di daerah penelitian (Gambar 13,14 dan Tabel 4).

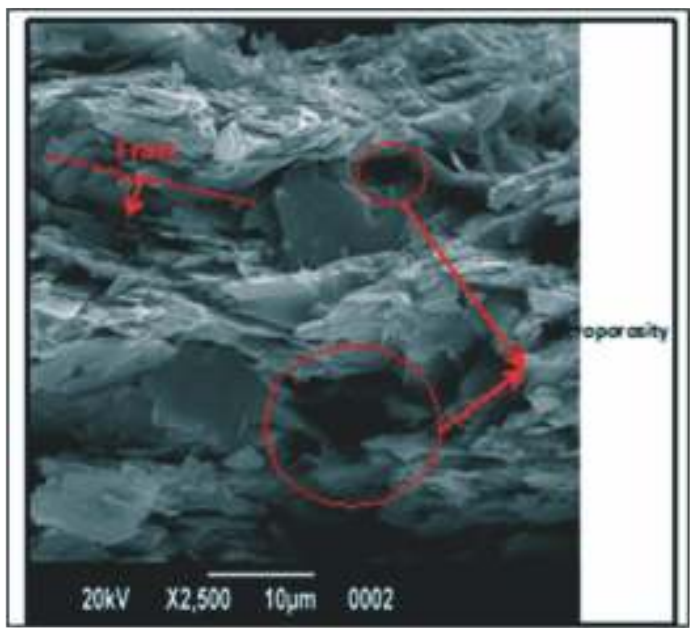

G ambar 13. Foto SEM sampel serpih Talao memperlihatkan porositas mikro dan rekahan. 


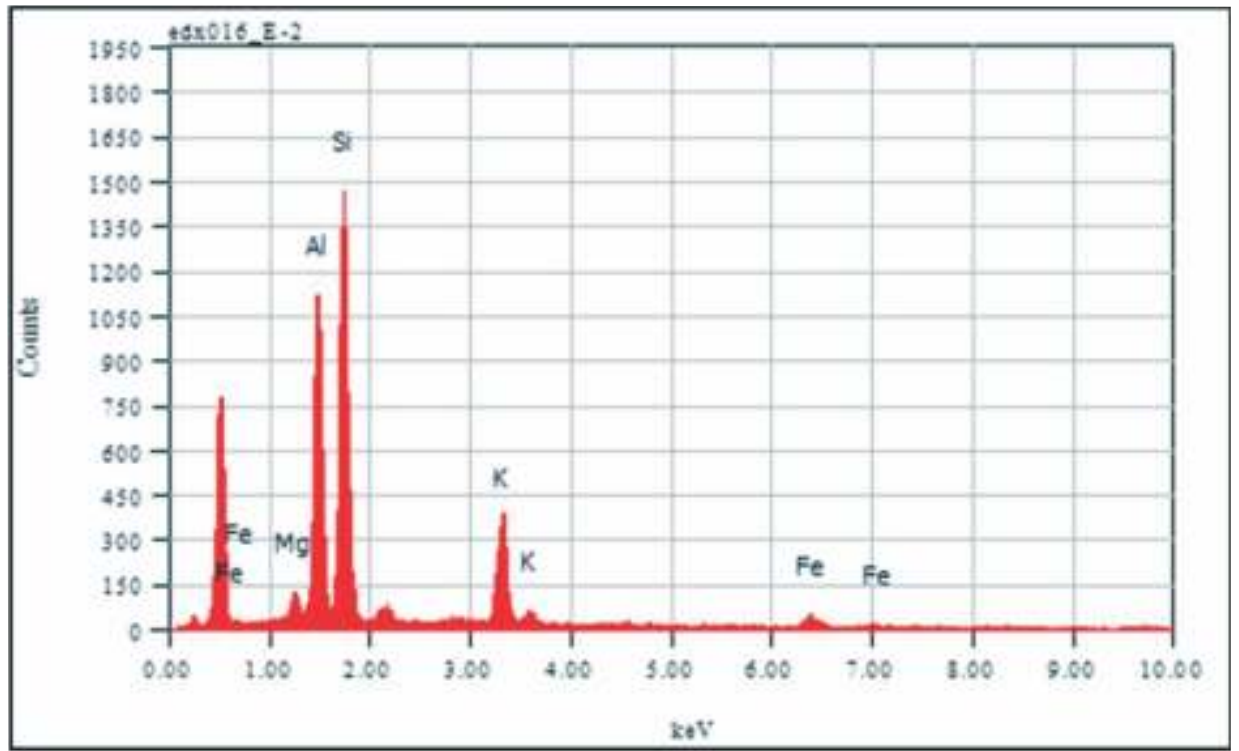

G ambar 14. Hasil analisis EDX sampel serpih.

Tabel 4. Hasil analisis kuantitatif sampel serpih Talao

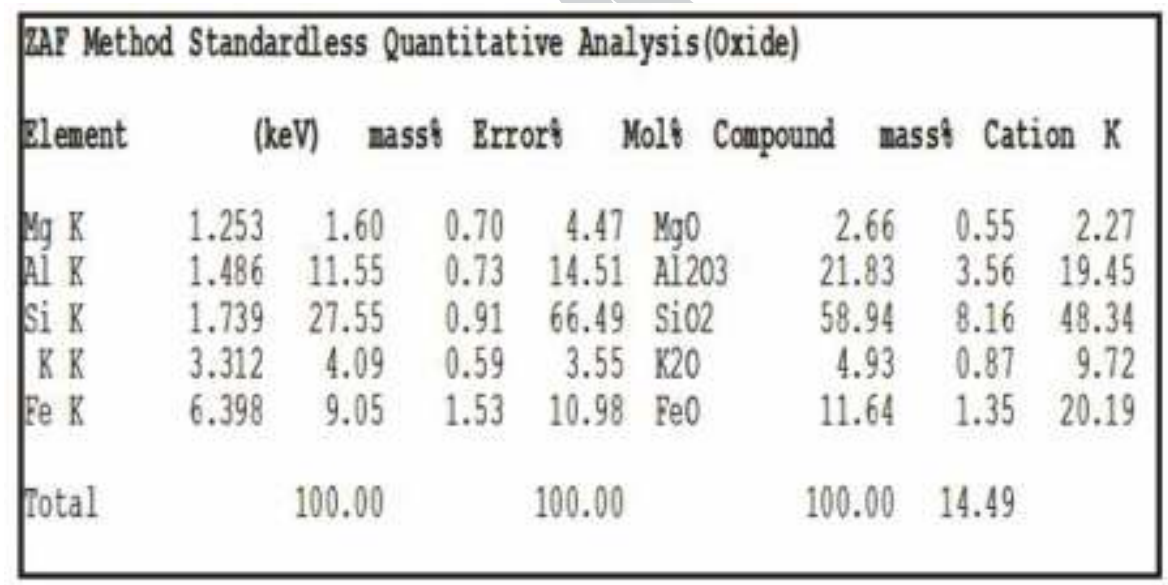

Dari hasil analisis contoh serpih daerah Talao didapat rata-rata silika $(\mathrm{SiO} 2)$ dalam batuan $58,94 \%$, secara kekerasan batuan ini tergolong brittle. $\mathrm{FeO}$ rata yang hadir pada contoh batuan 1-1,64 \% menunjukan tingkat oksidasi yang cukup tinggi.

\section{KESIMPULAN DAN SARAN}

Formasi Kuantan adalah formasi batuan berumur Permo-Karbon yang merupakan bagian dari Blok Sumatra Barat. Formasi Kuantan di daerah penelitian dibagi menjadi tiga satuan, yaitu Satuan Metamorf, Satuan Serpih dan Satuan Batugamping.

Berdasarkan ciri litologi yang diuraikan secara mikroskopis dan makroskopis dan juga kehadiran batupasir kuarsa arenit diperkirakan lingkungan pengendapan dari serpih Formasi Kuantan adalah daerah laut dangkal yang berasosiasi dengan daerah pantai.
Total Organic Content (TOC) serpih Formasi Kuantan yang didapatkan dari lima sampel serpih, yaitu $0,09 \%$ wt $-0,7 \%$ wt dengan Hidrogen Index (HI) $0-15 \mathrm{mg} / \mathrm{g}$. Nilai TAI pada serpih daerah penelitian adalah 2 sampai dengan 2+/3- dengan interval kematangan dari early mature sampai late mature atau sebanding dengan nilai Ro $0.6 \%$ - 0.9\% dan dengan Tmax 435-450, akan tetapi jika dilihat dari kehadiran grafit pada sayatan tipis, diperkirakan interval kematangan serpih Formasi Kuantan adalah over mature.

Berdasarkan hasil analisis SEM, didapat mineral lempung utama illit, kaolinit dan klorit hadir dalam jumlah yang lebih sedikit. Illit biasa juga disebut sebagai hydromuskovit yang memiliki struktur berlapis dan biasanya akan memberikan nilai porositas yang lebih baik jika dibandingkan dengan kaolinit. Ikatan atom kaolin lebih kuat dan rapat dibandingkan illit, sehingga porositas yang terbentuk akan semakin kecil, sedangkan ikatan atom illit lebih tidak stabil dan memungkinkan 
terbentuknya porositas yang lebih besar jika dibandingkan kaolin.

Hasil analisis petrologi, SEM dan EDX, serpih pada daerah penelitian memiliki kualitas yang cukup baik secara geomekanik karena memiliki kuarsa $(\mathrm{SiO} 2)>$ dari $50 \%$ dan persentase kehadiran illit dan kaolin yang lebih dominan dibandingkan dengan mineral kelompok smektit seperti monmorilonit sehingga akan memberikan respon yang baik jika dilakukan hydraulic fracturing.

Hasil analisis data geologi yang ditunjang dengan analisis geokimia mengindikasikan bahwa potensi gas serpih di daerah penelitian memiliki kemungkinan potensi gas serpih yang kecil. Kecilnya potensi ini diindikasikan oleh nilai kekayaan material organik yang rendah akibat kematangan yang tinggi dan kedalaman dari serpih yang relatif dangkal sehingga kemungkinan gas yang terbentuk lolos ke udara.

Diperlukan penelitian lebih lanjut dan detail untuk mengetahui potensi gas serpih pada batuan Mesozoikum Formasi Kuantan atau satuan batuan yang sebanding dengan Formasi Kuantan pada daerah lain di Indonesia bagian barat.

\section{ACUAN}

Barber, A.J. 2000. The Origin of the Woyla Terranes in Sumatra and the Late Mesozoic Evolution of the Sundaland Margin. Journal of Asian Earth Sciences, 18: 713-738.

Barber, A.J. and Crow, M.J. 2003. Evaluation of Plate Tectonic Models for the Development of Sumatra. Gondwana Research, 20: 1-28.

Barber, A.J., 2005. Sumatra: Geology, Resources and Tectonic Evolution. Geological Society, London, Memoirs 31.

Bjorlykke, K. , 2010. Petroleum Geochemistry, Mechanics, Confusion and Explanation. Springer, Berlin-Heidelberg.

Boggs, S. J.R., 1992. Petrology of Sedimentary Rock. University of Oregon, USA.

Bustin, R.M and Ross,D.J.K., 2008. Characterizing the Shale Gas Resource Potential of Devonian-Mississippian Strata in the Western Canada Sedimentary Basin: Application of an Integrated Formation Evaluation. AAPG Bulletin, 92(1): 87-125.

Cameron, N.R. and Pulonggono, A., 1984. Sumatran Microplate, Their Characteristics and Their Role in the Evolution of the Central and South Sumatra Basin. Proceeding Indonesian Petroleum Association, 13th, Jakarta, 121-143.

Chalik, K., 1996. Geologi dan Potensi Lempung Daerah Tanjung Alam dan Sekitarnya, Kecamatan Salimpaung, Kabupaten Tanah Datar, Sumatra Barat. Skripsi Program Sarjana, Institut Teknologi Bandung.

Dahl, B., Koefoed, J.B., Holm, A., Justwan, H., Rasmussen, E., dan Thomsen, E., 2004. A New Approach to Interpreting Rock-Eval S2 and TOC for Kerogen Quality Assesment. Journal Organic Geochemistry, 35: 1461-1477.

Folk, R. L., 1974. Petrology of Sedimentary Rock. hEMPHILL pUBL. cO., Austin Texas,

Fontaine, H. and Gafoer, S. (Eds), 1989. The Pre-Tertiary Fossils Of Sumatra And Their Environments. CCOP Technical Papers, 19,United Nations, Bangkok.

Fontaine, H. and Vachard, D., 1984. New Paleontological Data on the Upper Paleozoic of Sumatra. Memoires de la Societe Geologique de France, 147: 49-54.

Harmanto, Miswar, Adrial, Hariwidjaya, Suharsono, K., dan Lahar, H., 1992. Penyelidikan Geokimia Tindak Lanjut Daerah Sungai Balantik-Lampasi Kabupaten 50 Kota, Sumatra Barat. Direktorat Sumberdaya Mineral (tidak dipublikasikan).

Heidrick, T.L dan Aulia, K., 1993: A Structural and Tectonic Model of The Coastal Plain Block, Central Sumatra Basin, Proceedings Twenty Second IAGIAnnual Convention.

Hill. R.J., Zhang, E., Katz, B.J., and Tang, T., 2007. Modeling of Gas Generation from the Barnett Shale, Fort Worth Basin, Texas. AAPG Bulletin, 91(4): 501-521.

Justwan, H and Dahl, B., 2005. Quantitative Hydrocarbon Potential Mapping and Organofacies Study in the Greater Balder Area, Norwegian North Sea. Geology Society, London.

Koesoemadinata, R.P dan Matasak, T., 1981. Stratigraphy and Sedimentation, Ombilin Basin, Central Sumatra. Proceedings of the 10th Annual Conference, Indonesia Petroleum Association, Jakarta, h217-249. 
Koning,T., 1985. Petroleum Geology of the Ombilin Intermontane Basin, West Sumatra. Proceedings Indonesian Petroleum Association Fourteenth Annual Convention.

Metcalfe, I., 2011.: Tectonic Framework and Phanerozoic Evolution of Sundaland. Gondwana Research, 19: 3-21.

Montgomery, S.L., Jarvie, D.M., Bowker, K.A., and Pollastro, R.M., 2005. Mississipian Barnett Shale, Fort Worth Basin, North-Central Texas: Gas-Shale Play with Multi-Trillion Cubic Foot Potential. The American Association of Petroleum Geologists Bulletin, 89(2): 155-175.

Peters, K. E., 1986., Guidelines for Evaluating Petroleum Source Rock Using Programmed Pyrolysis. The American Association of Petroleum Geologists Bulletin, 70(3): 318-329.

Peters, K.E., and Cassa, M.R., 1994. Applied Source Rock Geochemistry. The American Association of Petroleum Geologists Memoir, 60 Chapter 5: Tulsa, Oklahoma USA.

Pollastro, R.M., 2007. Total Petroleum System Assessment of Undiscovered Resources in the Giant Barnett Shale Continuous (Unconventional) Gas Accumulation, Fort Worth Basin, Texas, The American Association of Petroleum Geologists Bulletin, 91(4):551-578.

Robertson, S. , 1999. Classification of Metamorphic Rock. British Geological Survey Research Report, RR 99-02.

U.S. Energi Information Administration, 2011. World Shale Gas Resources: An Initial Assesment of 14 Regions Outside the United States. U.S. Department of Energy, Washington.

Waples, D.W., 1985. Geochemistry in Petroleum Exploration. IHRDC, Boston.

Yeni, Y.F., 2014. Potensi Gas Serpih Formasi Kuantan Daerah Tabek Patah dan Sekitarnya, Sumatra Barat. Thesis Program Magister, Institut Teknologi Bandung. 